\title{
Świadomość własnej niepełnosprawności w życiu codziennym, środowisku szkolnym - refleksje uczniów z wadą wzroku
}

Niepełnosprawność niesie ze sobą wiele wyzwań. Są to wyzwania zarówno dla samej osoby, jak i dla społeczeństwa. Treścią niniejszego artykułu jest świadomość własnej niepełnosprawności, doświadczanie rzeczywistości społecznej, prawnej przez uczniów z wadą wzroku. Przedmiotem badań było doświadczanie niepełnosprawności i interpretacja rzeczywistości przez osoby z wadą wzroku. Celem badań było ukazanie rozumienia własnej niepełnosprawności w życiu codziennym, środowisku szkolnym przez uczniów z wadą wzroku. W badaniach strategii jakościowej wykorzystano analizę fenomenograficzną. Analiza transkrypcji wywiadów pozwoliła sformułować kategorie doświadczania niepełnosprawności przez badane osoby.

Słowa kluczowe: świadomość, niepełnosprawność, życie codzienne, uczeń z wadą wzroku, fenomenografia

\section{Awareness of own disability in everyday life, school environment - reflections of students with visual impairment}

A changing society confronts the individual with new dimensions of social, cultural and educational experiences. For people with disabilities, every change means the appearance of a barrier or barriers, which require appropriate conditions. The aim of this article is to present the understanding of disability in the school environment by students with visual impairment. Using the phenomenography method, students' with visual impairment experiences in the school environment were reconstructed. While analyzing the transcripts of the interviews, the categories of experiencing disabilities were formulated, and the main concepts of ways of experiencing the phenomenon of disability were examined.

Keywords: awareness, disability, everyday life, student with visual impairment, phenomenography method 


\section{Wprowadzenie}

Dynamicznie zmieniające się społeczeństwo stawia przed jednostką coraz to nowe wymiary doświadczeń społecznych, kulturowych, edukacyjnych. W codziennych działaniach każdy stara się dostosować, a jednocześnie zdobywać nowe kompetencje sprzyjające temu dostosowaniu i funkcjonowaniu, w warunkach zmiany. Reagując na różne czynniki wyzwala w sobie również działania kreatywne pozwalające na konstruowanie własnej tożsamości i utrzymanie relacji międzyludzkich. Takie przyspieszenie w wielu dziedzinach życia dla osób sprawnie działających jest sytuacją z pewnością nową, do której starają się jak najszybciej dostosować, wykorzystać własne możliwości, zintegrować z otoczeniem. Dla osób niepełnosprawnych każda zmiana oznacza pojawienie się bariery czy barier, na których pokonanie muszą mieć stworzone odpowiednie warunki, inne niż te dla osób pełnosprawnych. Osiągnięcie sukcesu w działaniu osób niepełnosprawnych zależne jest w dużym stopniu od pomocy i wsparcia innych, a także stosunku społeczeństwa do niepełnosprawności.

Niepełnosprawność niesie ze sobą wyzwania. Zarówno dla samej osoby, jak i dla społeczeństwa. Wśród wielu opinii, według D.D. Smith, niepełnosprawność sprawia, że uczestnictwo w życiu społecznym takiej osoby jest upośledzone, ale jednocześnie, ta niepełnosprawność nie istniałaby, gdyby społeczeństwo było zorganizowane inaczej (Smith 2011:34), odrzuciło instytucjonalną dyskryminację i uprzedzenie [Smith 2011: 35], a różnic między ludźmi nie określało sądami wartościującymi [Artiles 1998: 32-36]. Kłopot z jednoznaczną definicją pojęcia niepełnosprawność powoduje, że często niepełnosprawność postrzegana jest na poziomie jednostkowym i sprowadzana do ludzkich ograniczeń lub defektów (np. wada ciała, umysłu, kalectwo, choroba) [Przybylski 2010: 141-142]. W wymiarze doświadczeń i rozwoju wyklucza to procesy integracji osoby niepełnosprawnej, uczestnictwa w edukacji, kulturze i innych obszarach życia i społecznego funkcjonowania.

Współczesna definicja niepełnosprawności podkreśla przede wszystkim społeczny/środowiskowy kontekst, ,który stwarza warunki do większej partycypacji osób niepełnosprawnych w społeczeństwie” [Przybylski 2010: 143], ponieważ niepełnosprawność obejmuje „wiele ograniczeń funkcjonalnych, występujących w każdym społeczeństwie i w każdym kraju na świecie"1. Jak podkreśla J. Kirenko, to nie defekty indywidualne są przyczyną niepełnosprawności, ale brak możliwości zaspokajania potrzeb osób niepełnosprawnych i taka organizacja społeczeństwa, która wyklucza udział osób niepełnosprawnych w życiu społecznym poprzez tworzenie barier, a nie proponowanie odpowiednich usług osobom

1 Rezolucja nr 48/96 ONZ: https://www.rpo.gov.pl/pl/content/akty-prawne-0. 
niepełnosprawnym [Kirenko 2007: 46-47]. W niniejszym artykule przyjęto model społeczny niepełnosprawności, którego tezy uzupełniają także cele standardowych zasad wyrównywania szans, a mianowicie "zagwarantowanie niepełnosprawnym [...] jako członkom swoich społeczności, możliwości korzystania z tych samych praw i obowiązków przysługujących pozostałym obywatelom, podejmowania działań i współpracy [...] o decydującym znaczeniu dla jakości życia i osiągania pełnego uczestnictwa" 2 w życiu społecznym. Kluczowym obszarem funkcjonowania osoby niepełnosprawnej, w którym nabywa ona niezależność, radość i sukces życiowy jest od najmłodszych lat, system edukacji. Przyjęty model społeczny daje szansę na likwidację istniejących barier, które ograniczają aktywność i uczestnictwo osób, o różnych rodzajach i charakterze niepełnosprawności, w życiu społecznym, szczególnie osób z wadą wzroku, których dotyczy treść tego artykuł.

Za niedowidzenie przyjęto „zaburzenie widzenia lub niski poziom widzenia, poważną redukcję widzenia, która nie może być korygowana za pomocą standardowych okularów lub soczewek kontaktowych. Zmniejsza ona zdolność osoby do pracy lub wykonywania niektórych zadań"3, ale jak uważa T. Majewski, „Wzrok pozostał nadal głównym źródłem poznania rzeczywistości, [...] osoba taka w różnych sytuacjach życiowych w głównej mierze wykorzystuje informacje, jakie dostarczają jej bodźce wizualne, choć ich zakres jest znacznie ograniczony w porównaniu z osobami widzącymi..." [Majewski 1983: 157].

Badania, prowadzone przez S.A. Curry i P.H. Haltena, dotyczące zaspokajania potrzeb edukacyjnych i istnienia barier w funkcjonowaniu osób niedowidzących, pozwoliły na sformułowanie wniosków na temat zmian, które nastąpiły w zakresie barier. Według badaczy należy wyróżnić zmiany:

- strukturalne - obserwowane na poziomie lokalnym, do których należy zaliczyć indywidualne, specjalne programy edukacyjne wychodzące poza tradycyjnie zorganizowany dzień szkolny, specjalny dla uczniów niedowidzących;

- filozoficzne - dotyczące akceptacji, wsparcia nauczycieli, rodziców w zaspokajaniu potrzeb edukacyjnych uczniów niedowidzących;

- finansowe - pomoc pieniężna różnego charakteru, ponieważ nauka uczniów niedowidzących jest dodatkowym, finansowym obciążeniem nie tylko rodziców dzieci, ale i szkoły, dlatego należy kształcenie postrzegać w kontekście długoterminowych korzyści w środowisku społecznym;

- integracji w zakresie postaw społecznych - asymilacja w społecznościach osób widzących poprzez uczestniczenie $\mathrm{w}$ działaniach edukacyjnych i rekreacyjnych uczniów niedowidzących i ich rodziców;

- wspieranie i rozwijania umiejętności - działania zmierzające do wychodzenia poza przypisane przez społeczeństwo role osobom niepełnosprawnym po-

$\begin{array}{ll}2 & \text { Rezolucja nr 48/96 ONZ: https://www.rpo.gov.pl/pl/content/akty-prawne-0. } \\ 3 & \text { http://medical-dictionary.thefreedictionary.com/Visual+Impairment. }\end{array}$ 
przez m.in. poszukiwanie różnych form komunikacji [Curry, Halten 2007, www.eccadvocacy.org/section.aspx?TopiclD $=451 \& D o c u m e n t I D-5282]$. Istotne znaczenie $\mathrm{w}$ redukowaniu barier i wprowadzaniu zmian, ma przede wszystkim aprobata dla działań podejmowanych przez instytucje na różnych szczeblach, od centralnego po lokalne, celem poprawy funkcjonowania osób niepełnosprawnych $\mathrm{w}$ społeczeństwie. Instytucją, która w szczególny sposób powinna rozwiązywać problemy barier w kształceniu dzieci i młodzieży z niepełnosprawnością i jednocześnie zmieniać się, jest szkoła. Szkolnictwo, zwłaszcza publiczne, powinno zaspokajać wyjątkowe potrzeby edukacyjne, wskazywać mocne strony, predyspozycje, maksymalizować potencjał rozwojowy, dawać szansę na zawodowe, niezależne życie.

\section{Uczeń z niepełnosprawnością w szkole}

Ustawa z dnia 14 grudnia 2016 r. Prawo oświatowe (Dz. U. z 2017 r., poz. 59) uwzględnia zadania nauczycieli i szkoły wobec dzieci i młodzieży niepełnosprawnych. W zależności od potrzeb uczniów, na każdym etapie systemu edukacji począwszy od przedszkola, system oświaty zapewnia „opiekę nad uczniami niepełnosprawnymi przez umożliwienie realizowania zindywidualizowanego procesu kształcenia, form i programów oraz zajęć rewalidacyjnych" (Dz. U. z 2017 r., poz. 59: 1], a nauczyciel ma za zadanie rozpoznawać i wspierać możliwości rozwojowe dzieci, w razie potrzeby podejmować wczesną interwencję, organizować zajęcia rewalidacyjne, skierować do instytucji specjalistycznych w celu „pogłębionej diagnozy związanej ze specjalnymi potrzebami edukacyjnymi" [Dz. U., poz. 356: 8]. W momencie ujawnienia specyficznych potrzeb ucznia „organizuje się kształcenie i wychowanie, które stosowanie do potrzeb umożliwia naukę $\mathrm{w}$ dostępnym [...] zakresie, usprawniania zaburzonych funkcji, rewalidację [...] oraz zapewnia specjalistyczną pomoc i opiekę" [Dz. U., poz. 356: 56]. Z dniem 1 września 2017 r. weszło w życie rozporządzenie MEN z dnia 9.08.2017 r. w sprawie warunków organizowania kształcenia, wychowania i opieki dla dzieci niepełnosprawnych, niedostosowanych społecznie i zagrożonych niedostosowaniem społecznym [Dz. U. z 2017 r., poz. 1578]. W świetle nowych rozporządzeń najbardziej znaczące są ustalenia w sprawie zajęć rewalidacyjnych, dokonywania okresowej wielospecjalistycznej oceny poziomu funkcjonowania ucznia w szkole, a także możliwość zatrudniania dodatkowych nauczycieli (specjalistów, nauczycieli wspomagających). Zostały też sprecyzowane zasady i zakres wspólpracy rodziców z nauczycielami. Wprowadzone rozporządzeniem zmiany są potrzebne i korzystne dla uczniów z niepełnosprawnością, realizujących kształcenie w szkołach ogólnodostępnych, ich rodziców oraz nauczycieli. Uwzględniają specjalne potrzeby edukacyjne dzie- 
ci, a przede wszystkim zobowiązują szkołę, jako instytucję, do zapewnienia warunków techniczno - organizacyjnych, specjalistycznej i wspomagającej kadry pedagogicznej. Podstawy prawne należy oczywiście systematycznie wdrażać, realizować, aby służyły podmiotowemu traktowaniu ludzi, których dotyczą i doskonaliły budowany od wielu lat system edukacji.

Szczególną rolę w procesie kształcenia w szkole odgrywa dobrze wykształcona, specjalistyczna kadra pedagogiczna. W przypadku ucznia z wadą wzroku, wiedza i umiejętności powinny obejmować, poza przygotowaniem merytorycznym do prowadzenia przedmiotu, wiele innych umiejętności pracy z uczniem. Są to: organizowanie funkcjonalnego miejsca pracy, umiejętne wykorzystywanie specjalistycznych pomocy (optycznych, dydaktycznych), nowoczesnych technologii, dostosowywanie metod i form pracy do możliwości ucznia słabo widzącego. Ponadto współpraca z rodzicami poprzez nawiązanie otwartej relacji, informowanie o przebiegu i efektach pracy dydaktyczno-wychowawczej dziecka, zrozumienie i wsparcie dla podejmowanych przez rodziców działań. „Coraz częściej podkreśla się dzisiaj, że podstawowym warunkiem dobrego przygotowania do życia jest przede wszystkim społeczne funkcjonowanie w środowisku rówieśniczym, w przedszkolu, w szkole, a następnie umiejętność harmonijnego współżycia w życiu dorosłym, a zwłaszcza zawodowym. Drogą do osiągnięcia tego celu jest kształcenie dzieci niepełnosprawnych razem z rówieśnikami pełnosprawnymi" [Marek-Ruka 2010: 19]. Równy dostęp do specjalistycznych programów umożliwi im skuteczne konkurowanie z rówieśnikami, w społeczeństwie.

Świadomość własnej niepełnosprawności, doświadczanie rzeczywistości społecznej, prawnej przez uczniów z wadą wzroku jest treścią niniejszego artykułu, w którym świadomość rozumiana jest jako „,szczególny rodzaj wewnętrznej reprezentacji rzeczywistości, jej wewnętrzny obraz, model, odbicie" [Tomaszewski 1978:171] oraz jako "wewnętrzny, subiektywny stan zdawania sobie sprawy z czegoś" [Reber 2002: 740]. Doświadczanie niepełnosprawności w życiu codziennym, w życiu szkolnym wpływa na postępowanie jednostki, jej stosunek do rzeczywistości i jak twierdzi T. Tomaszewski [1978: 171] „fakt uświadamiania sobie [...] przez człowieka jego sytuacji ma istotne znaczenie dla jej kształtowania się oraz dla przebiegu zachowania się jej podmiotu".

\section{Założenia metodologiczne}

Celem badań było ukazanie rozumienia własnej niepełnosprawności w życiu codziennym, środowisku szkolnym przez uczniów z wadą wzroku, ponieważ w zależności od doświadczania w życiu codziennym, szkolnym swojej niepełnosprawności, kształtuje się jej świadomość. Problem badawczy został sformułowa- 
ny następująco: jaka jest świadomość własnej niepełnosprawności w życiu codziennym, środowisku szkolnym, uczniów z wadą wzroku? W badaniach strategii jakościowej wykorzystano analizę fenomenograficzną. Przedmiotem zainteresowania było rozumienie świata doświadczanego przez jednostkę w różny sposób [Bielecka-Prus 2012: 91-93], interpretacja rzeczywistości przez osoby z wadą wzroku. W badaniach wykorzystano wywiad indywidualny, częściowo ustrukturyzowany, przeprowadzony z trzema licealistkami (Anną z wadą wzroku -9D, Kamilą z wadą wzroku -10D, Moniką z wadą wzroku -10D), uczęszczającymi na zajęcia rewalidacyjne, w jednym z liceów w Elblągu. Przedmiotem analizy były teksty transkrypcji przeprowadzonych wywiadów indywidualnych.

\section{3. Świadomość własnej niepełnosprawności w uczniów z wadą wzroku}

Analizując transkrypcje wywiadów określono przestrzeń wynikową, która pozwoliła wstępnie sformułować kategorie doświadczania niepełnosprawności, w środowisku szkolnym, w świadomości osób niedowidzących. Są to: rozumienie niepełnosprawności, czynności życia codziennego, funkcjonowanie w grupie rówieśniczej, trudności w procesie kształcenia, udział w zajęciach rewalidacyjnych, plany na przyszłość. Na podstawie analizy wyłonionych kategorii opisu ujawniono koncepcje doświadczania niepełnosprawności przez osoby niedowidzące.

Niepełnosprawność jako dostosowanie i walka w życiu codziennym

Badane osoby osobiście doświadczają niepełnosprawności, dlatego w ich przypadku ważny jest kontekst sytuacyjny, w który wpisuje się kategoria: niepełnosprawność jako ograniczenie. W narracjach badanych niepełnosprawność jest ograniczeniem, brakiem lub utratą czegoś, co powinno funkcjonować prawidłowo. Anna, jedna z respondentek, definiuje niepełnosprawność następująco:

jest to pewnego rodzaju blokada, niedogodność, z która trzeba walczyć, ale wcześniej moim zdaniem trzeba ją zaakceptować. (...) jest to coś w rodzaju kompleksu i główne ograniczenia są wina naszego umystu a nie ciała. Oczywiście sa momenty, w których najchętniej chcielibyśmy uciec od swojej niepetnosprawności, a poczucie, że jest to na chwile obecna, jest to niemożliwe jeszcze bardziej nas irytuje i zasmuca...

Kamila, kolejna z badanych, zauważa, że:

niepetnosprawność jest fizycznym odejściem od prawidłowego funkcjonowania danych części ciała, [...] coś co nie pozwala ludziom w petni aktywnie funkcjonować w społeczeństwie. Może wynikać z różnorodnych chorób, w tym także psychicznych. Monika, trzecia z badanych, nazywa niepełnosprawność dysfunkcją, która ogranicza wybór danego zawodu. 
Badane poza sformułowaniami blokada, niedogodność, kompleks, odejście od prawidłowości, niepełnosprawność określają jako „coś” co zabiera prawidłowe funkcjonowanie części ciała, aktywność w społeczeństwie, ogranicza umysł, wybór zawodu. W opisywaniu niepełnosprawności przez badane pojawia się zaimek nieokreślony „coś”. Może to sugerować, że narratorki nie chcą lub nie potrafią dokładnie sprecyzować swoich odczuć. Jest to ich własne doświadczenie, świadomość niepełnosprawności, i jak opisuje to Anna: jesteśmy w stanie dostosować swoje życie tak, by jak najmniej odczuwać, że nie jesteśmy w stanie robić czegoś tak samo, jak osoby w petni sprawne, więc przytaczane definicje, opisy mogą przybliżyć, pozwolą w pewnym aspekcie zrozumieć, ale nie oddadzą w całości poczucia, co to jest niepełnosprawność samego podmiotu. Muszą przystosować się tak, aby doświadczana niepełnosprawność jak najmniej wpływała na ich życie.

Indywidualne doświadczanie świata przez osoby z wadą wzroku opisywane było przez narratorki przede wszystkim w kontekście czynności dnia codziennego, w których najbardziej przeszkadzała im niepełnosprawność. Anna bardzo konkretnie opowiada o swoich zachowaniach w domu:

jestem osobą z krótkowzrocznością i niedowidzeniem, więc moje problemy skupiają się na tym, że zwyczajnie nie widzę wyraźnie tego, co widzą inni. Przebywając w domu, nosząc okulary czy soczewki kontaktowe nie napotykam żadnych trudności. Gorzej jest jednak, gdy po zdjęciu soczewek muszę znaleźć swoje okulary. Przeszukuję wszystkie miejsca w domu, czasem po omacku, bo wieczorem przy słabym oświetleniu moge ich nie zauważyć nawet, gdy leża tuż przede mną. Byłoby łatwiej gdybym zawsze odkładała je na miejsce, lecz jednak człowiek nie zawsze uczy się na błędach (uśmiech).

W swojej narracji Anna, trochę z humorem, może ironicznie podkreśla, że niepełnosprawność, w codziennych domowych czynnościach, doświadcza jako „poszukiwanie" okularów lub soczewek, których sama nie odkłada na miejsce i choć powinna, nie uczy się na własnych błędach. Ale w jej narracji można wyodrębnić krótki fragment mocnej argumentacji, że problemy z doświadczaniem życia codziennego skupiają się na tym, że nie widzi wyraźnie tego, co widzą inni. Ten argument może pomóc wyjaśnić te części wypowiedzi Anny dotyczące rozumienia pojęcia niepełnosprawność, w kontekście walki, akceptacji. Kolejna badana, Kamila, opowiadając o czynnościach dnia codziennego, stwierdza, że:

wada wzroku przeszkadza mi przede wszystkim w nauce, czytaniu, korzystaniu z komputera. Kiedy zdarza się sytuacja, że moja soczewka wypada, nie trzyma się na miejscu, bądź zachodzi mgta nie jestem w stanie wykonać żadnej czynności samodzielnie. W przypadku okularów trzęsie mi sięobraz, mam ograniczone pole widzenia i zazwyczaj za słabe szkła (co kilka miesięcy musiałabym zmieniać szkła, co jest dużym wydatkiem). Z tego powodu jestem często rozkojarzona i skupiam się głównie na tym, że nie widzę w petni wyraźnie, dobrze i "czysto" (oczy zachodzą mi mgta). 
Dla niej najważniejsze czynności związane są z nauką i możliwością korzystania z nowoczesnych technologii. Obiektywne przeszkody ograniczają widzenie, powodują przykre odczucia, trochę bezradność i dyskomfort, przypominają o chorobie, również w aspekcie materialnym. Monika, trzecia z narratorek, nie dostrzega trudności w codziennym funkcjonowaniu:

na co dzień nie doświadczam żadnych większych problemów związanych z tą dysfunkcją. Jedynie w zimie kiedy wchodzi się do pomieszczenia i przez kilka minut nie jest w stanie się nic zobaczyć i jednocześnie podkreśla, że u mnie, czyli przypadku dużej wady wzroku problem pojawia się przy pływaniu bądź uprawianiu jakiegoś sportu, w którym okulary mocno przeszkadzają.

Wydaje się, że Monika skonstruowała swój świat i czynności życia codziennego w oparciu o poczucie niezależności, radzenia sobie w sytuacjach trudnych i chęć podejmowania odważnych działań.

Doświadczanie życia codziennego i trudności z tym związanych, np. w przestrzeni publicznej, jako jedyna z badanych, opisuje Anna. Oto jej wypowiedź:

idąc do kina, staram się wybierać miejsca, które nie sa najdalej od ekranu, szczególnie, gdy wybieram się na film z napisami. Sa duże, ale czasem moga się rozmazywać, a przy szybkim czytaniu jest to spora niedogodność. Moją największą zmora, jak się zastanowię, sa jednak przystanki autobusowe i kawiarnie lub bary, które swoje menu mają wywieszone jedynie na ścianach za ladą. W przypadku przystanków autobusowych, gdy widzę, że jacyś ludzie usiedli zaraz pod tablica z rozkładem, od razu wiem, że się spóźnię. Żeby dostrzec, co jest napisane na rozkładzie musze podejść naprawdę blisko, a nie chcę nikomu wchodzić na kolana. Czasem wystarczy poprosić kogoś, by się troszkę odsunąt, lecz niektórzy udaja, że mnie nie styszą. A jeśli chodzi o kawiarnie, jeśli nie maja kart, które mogę wziać do ręki i spokojnie przeczytać, co oferuja, lub nie przyszłam z nikim, kto mógłby mi przeczytać, co jest wywieszone na tablicach, pozostaje mi tylko poszukać innego miejsca.

W przestrzeni publicznej Anna stara się radzić sobie z ograniczeniami, które posiada, i które spotyka w środowisku społecznym. W swojej wypowiedzi ujawnia wiele barier uniemożliwiających jej codzienne funkcjonowanie (np. dojazd do szkoły). Bariery architektoniczne, społeczne, kulturowe narażają ją na kłopoty lub rezygnację z planów, z przyjemności.

Wspólne kategorie interpretacyjne, które ujawniły się w wypowiedziach badanych i odkryły strukturę doświadczenia to: poszukiwanie, codzienna „walka”, akceptacja, bezradność, niezależność, rezygnacja. Perspektywa postrzegania życia codziennego poprzez świadomość czynności jest bardzo różna w odczuciach badanych. Czasami odczucia te nawzajem się wykluczają. To sytuacje w świecie społecznym, niezależne od tych kobiet, projektują wybór określonych zachowań niepełnosprawnych. 


\section{Niepełnosprawność jako wsparcie rówieśników i trudności w uczeniu się}

Ta kategoria opisu pojawiła się w kontekście szkoły i sposobów funkcjonowania badanych w klasie. Oto przykład wypowiedzi Anny:

wydaje mi się, że zawsze miatam szczęście, spotykają jedynie takich ludzi, którzy w krótkowzroczności nie widzieli nic zabawnego. Traktowali mnie, jak innych, którzy mieli doskonaty wzrok. Nie wspótczują mi, ponieważ nigdy nie mieli ku temu okazji. Nie wyżalatam się im, że czegoś nie widzę. Natomiast zawsze mi pomagaja. Gdy nie widzę czegoś doktadnie, proszę moja koleżankę lub mojego kolegę, czy mogliby powiedzieć co jest napisane na tablicy. Rozumieja, że mogę mieć problem z odczytaniem niektórych rzeczy. A jeśli siedziatam w szkolnej ławce a kimś, kto także miał problemy ze wzrokiem, zdarzało się, że to ja pomagałam innym. Nie ma się czego wstydzić i trzeba się nawzajem wspierać.

Anna nie odczuwa w szkole ze strony rówieśników współczucia, wyręczania, szczególnego traktowania z powodu niepełnosprawności. Jej sposób funkcjonowania w szkole opiera się na współpracy koleżanek i kolegów i ich wsparciu w sytuacjach szkolnych. Nie opowiada jednak o pomocy ze strony nauczycieli przedmiotów, zmiany np. metod pracy na lekcji, w jej przypadku. Kamila, kolejne z badanych, opisuje swoje doświadczenie szkolne ze świadomością wady, którą posiada. Swoje sposoby funkcjonowania w szkole porównuje z rówieśnikami:

ze względu na moją bardzo dużą wadę (-10) jestem zmuszona nosić okulary bądź soczewki. To jednak nie powoduje, że jestem w petni sprawna pomimo tych specjalistycznych pomocy. Jestem dużo wolniejsza od moich rówieśników, często boli mnie gtowa, a okulary powoduja, że nie mam petnego pola widzenia.

Kamila wskazuje na swoje ograniczenia w szkole, ale nie odczuwa specjalnego traktowania niepełnosprawności przez rówieśników, uważa, że są niepełnosprawności poważniejsze: rówieśnicy jednak nie uważają mojego problemu za niepetnosprawność, fakt faktem sa poważniejsze niepetnosprawności od mojej, ale w dalszej części wypowiedzi identyfikuje się z osobami z tym samym rodzajem niepełnosprawności, ponieważ: Jedynie osoby z wadami wzroku rozumieja w czym jest problem. Natomiast od koleżanek i kolegów w szkole otrzymuje wsparcie i pomoc, o której opowiada następująco: kiedy w szkole nie nadażałam z przepisywaniem, to prositam kogoś o możliwość podestania notatek i zazwyczaj byli chętni do pomocy, i nie wydaje się to czymś wyjątkowym, jak naturalną życzliwością osób uczących się razem, i stanowiących zespół klasowy. Wśród rówieśników, Annę spotykają też sytuacje zabawne, które opisuje z dystansem do rzeczywistości, jako nowe doświadczenie swoje, ale równocześnie doświadczenie jej koleżanek, kolegów z klasy:

...zabawna sytuacja jest wtedy, gdy ktoś prosi mnie, bym pozwoliła mu przymierzyć moje okulary. Zawsze się zgadzam, ponieważ nie widziatam nic śmieszniejszego od ludzi, których moje szkło z moca -9 powalato na topatki. Większość ze śmiatków nie zatożyła jeszcze okularów na nos, 
a już odsuwali się od nich na dtugość ramion. Dla nich wszystko wydaje się rozmazane, a po paru chwilach zaczyna boleć głowa. Nic dziwnego, to spora moc szkieł. Kilka razy zostałam również zapytana czy cokolwiek widzę, skoro mam tak dużą wadę...

Bardzo zdawkowo opisuje swoje doświadczenia z rówieśnikami Monika, ponieważ mimo wady wzroku -10D, uważa, że ...moja dysfunkcja nie jest na tyle problematyczna, żeby moi rówieśnicy musieli mnie w czymś wyręczać. Chociaż zdarzało się parę razy, że nie widziałam jakiegoś napisu i ktoś musiał mi go przeczytać..., otrzymuje pomoc i wsparcie od uczniów w klasie i chyba to jej wystarczy, żeby czuć się dobrze, nie sprawiać kłopotów innym.

Dobre samopoczucie w grupie sprzyja procesowi kształcenia, jednak jak wskazuje wcześniejsza refleksja badanych, doświadczają one określonych trudności w tym procesie. W wypowiedziach na temat największych trudności w procesie kształcenia i chęci zmiany Kamila podkreśla jednak „inność” jej funkcjonowania w szkole.

Największą trudność sprawia mi zdecydowanie robienie wszystkiego dużo, dużo wolniej od in$n y c h . .$. i najbardziej chciałaby zmienić to żeby nauczyciele respektowali, że ktoś robi pewne zadania wolniej i skoro ma prawo do wydtużonego czasu na maturze to powinien je mieć również na sprawdzianach i przede wszystkim na maturach próbnych (zaznaczając, ze nie miałam możliwości napisać matury próbnej w moim przedziale czasowym, mając do dyspozycji tylko czas podstawowy).

Kamila również nie doświadcza wsparcia ze strony nauczycieli na zajęciach w klasie. Błędy nauczycieli i szkoły (systemu oświaty) ograniczają, zdaniem Kamili, spełnianie odpowiednio wymagań szkolnych.

Monika o swoich doświadczeniach w nauce opowiada w kontekście pogodzenia się z trudnościami: ... ból oczu pojawia się po dłuższym wytężaniu wzroku, kiedy chcę coś przeczytać z tablicy bądź długo siedzę i się uczę. Jednak to nie jest niczyja wina, więc nie ma jak tego zmienić. A jeśli chodzi o większe litery na sprawdzianach czy egzaminach to nie ma problemu, miałam to już w szkole... Wszystkie przeszkody rozumie i nie chce zmieniać czegoś, co nie jest jej zdaniem do zmiany, ponieważ wynika z przyczyn naturalnych, a nie zamierzonych.

Niepełnosprawność jako poznawanie świata „inaczej” i realizowanie marzeń

Badane bardzo chętnie opowiadały o swoich zajęciach rewalidacyjnych, na które chodzą systematycznie i z przyjemnością. W liceum, do którego uczęszczają zajęcia prowadzi specjalista -tyflopedagog, pracujący na co dzień w szkole. To duża zaleta. Badane czują się bezpiecznie w każdej trudnej dla nich sytuacji szkolnej mając na miejscu osobę, która stara się rozpoznać problem związany z ich niepełnosprawnością. 


\begin{abstract}
Anna tak opisuje:
na zajęciach rewalidacyjnych oprócz gier, które byly interesujące i pozwalały spędzić miło czas ze znajomymi z zajęć, najbardziej przypadty mi do gustu ćwiczenia z wykorzystaniem zmysłów. Zajęcia stuchowo-pamięciowe, gdzie trzeba było powtarzać coraz bardziej skomplikowane sekwencje oraz zajęcia z wykorzystaniem wyłacznie dotyku. Zawsze mnie fascynowało to jak inaczej odbiera się dokładnie ten sam przedmiot wyłacznie trzymając go w dtoniach, a jak po tym, kiedy już go zobaczymy. Gdy miałam zasłonięte oczy samo wyciagnięcie ręki po dany przedmiot wywotywało ciekawość $i$ strach, ponieważ nigdy nie wiadomo, czy nagle nie spadnie nam na ręke pająk! Poza tym pobudza to wyobraźnię. Staram się wtedy odtworzyć ksztatt, wielkość i strukturę czegoś, czego nie mogę zobaczyć. Bardzo fajnym doświadczeniem było również rysowanie po śladach dwóch różnych obrazków, dwiema rękami w tym samym czasie. Miałam wrażenie, że co jakiś czas mój mózg zamieniat, nad która dtonia mam w danym momencie więcej kontroli i na której bardziej się skupiam, Było to zabawne, lecz strasznie męczace.
\end{abstract}

Doświadczanie świata przez stymulację różnych zmysłów sprawiało, że badana dobrze zapamiętała emocje, jakie wtedy odczuwała: przyjemność, ciekawość, fascynację, strach i duży wysiłek. Ale też nadawała nowe znaczenia poznawanym przedmiotom, zjawiskom, rozwijała wyobraźnię.

Kamila, opowiadając o zajęciach rewalidacyjnych, wymienia konkretne umiejętności, które rozwijała:

...najbardziej lubiłam zabawy z klockami przestrzennymi, pozwalaty mi na rozwijanie mojego zmystu przestrzennego. Również ćwiczenia polegające całkowicie na zmyśle dotyku, ponieważ mogłam skupić się na czuciu, dając moim oczom czas na odpoczynek. Uwielbiałam tė̇ klocki z lipona, w których trzeba było ułożyć parę różnych elementów w określony ksztatt, np. literę " $T^{\prime \prime}$. Granie w scrabble pomagato mi rozwinać zakres mojego stownictwa, a szukając krążków z wyrzuconymi na kostce przedmiotami poprawiałam swoją spostrzegawczość.

Praca innych zmysłów pozwoliła „odpocząć oczom”, wyostrzyła orientację przestrzenną, spostrzegawczość, odczuwanie świata poprzez dotyk. Takie korzyści wymienia Kamila z uczestnictwa w zajęciach rewalidacyjnych. Monika też bardzo ceni zajęcia i podkreśla osiągane efekty pracy:

... najbardziej lubię gry na spostrzegawczość, gdyż one pomagaja wtedy podczas pisania prac, kiedy trzeba zauważyć swoje błędy. Zauważyłam również, że po takich zajęciach nie mam problemu z przestawianie liter a także z ich gubieniem, co było u mnie dość częste.

Monika podczas zajęć rewalidacyjnych doświadcza przydatnych, praktycznych umiejętności. Potrafi określić ich zalety i sposób wykorzystania w przyszłości.

W wypowiedziach badanych ujawniło się jakościowo różne rozumienie poznawanego świata podczas zajęć rewalidacyjnych. Odkrywały one skrajne emocje, ciekawość zmysłów, wyobraźnię i konkretne umiejętności, które mogą wykorzystać w przyszłości, w życiu codziennym. 
Niepełnosprawność nie musi ograniczać zainteresowań i przyszłych planów życiowych. Badane mają swoje marzenia, które chcą realizować. Świadomość swojej sytuacji, a jednocześnie plany na przyszłość, w wypowiedzi tak ujawnia Anna:

ze względu na swoją krótkowzroczność nie mogłabym zostać chirurgiem. Na całe szczęście nie chce nim być. Interesuję się głównie rzeczami związanymi ze sztuka, jak rysowanie, pisanie, śpiewanie lub kręcenie filmów, a także językami obcymi, a nawet tym, jak działa ludzki umyst, czy idąc dalej jak działa wszechświat, w którym się znajdujemy. Uważam, że jestem osoba, która interesuje wiele rzeczy, z różnych dziedzin i nie pozwolę, żeby moja niepetnosprawność przeszkodziła mi w cieszeniu się tymi rzeczami. Nigdy nawet nie pomyślałabym, że mój wzrok może mi w tym przeszkodzić. Na razie planuję iść na studia, a potem zdobyć pracę, lecz kto wie, jak potoczy się moje życie (...) wiele może się zmienić.

Anna odkrywa też swoje marzenia związane z doświadczaną niepełnosprawnością:

... jest jednak jedna rzecz, która planuję od lat, a na początku głównie planowali moi rodzice. Jest to laserowa korekta wzroku. Być może w niedalekiej przyszłości będę mogła cieszyć się wyjściem na dwór bez okularów i mam nadzieję, że któregoś dnia nie będę już należała do kręgu osób niepetnosprawnych. Nie jest to oczywiście nic, co sprawia mi przykrość, ale cieszę się, że jest możliwość pozbycia się mojej choroby. Bardzo na to liczę. Jestem ciekawa jak to jest widzieć wyraźnie catą dobę, bez żadnych pomocy. Wadę mam od maleńkości, więc do tej pory nigdy tego nie zaznatam, a przynajmniej nie pamiętam.

W wypowiedzi Anny odsłania się jej indywidualna relacja z życiem codziennym, inny świat od dzieciństwa, chęć poznania tego „prawdziwego świata” i wyjścia z „kręgu” osób niepełnosprawnych.

Zainteresowania Kamili są bardzo różnorodne:

...uwielbiam czytać ksiązki, surfować po Internecie i ogląać seriale. Moim zamiłowaniem są różnorodne, aktywności fizyczne i zdrowe odżywianie, dzięki któremu odkryłam pasję do gotowania, ale jej plany na przyszłość związane są z działalnością artystyczną: czuję też potrzebę tworzenia: malowanie, rysowanie, fotografia to coś dzięki czemu się wyrażam. Jeszcze nie wiem kim bym chciała być w przyszłości, ale chciałabym zarabiać na życie działalnościa artystyczna. Chcę się rozwijać poprzez uczestnictwo w różnorodnych kursach, chodzenie na koncerty i do teatrów.

Kamila ma świadomość swoich zdolności twórczych i w pełni chce je wykorzystać.

Monika w planowaniu przyszłości i opisywaniu zainteresowań opowiada krótko i zwięźle:

moim zainteresowaniem zawsze był teatr. Dlatego bardzo chciałabym robić coś z tym zwiazanego. Jednak jest to zawód bardzo niepewny, dlatego wybieram się na politechnikę. Jednak postaram się uczestniczyć w jakiś zajęciach dodatkowych (teatralnych) na studiach. 
Opowiadając o własnej przyszłości badana kieruje się wymaganiami praktycznymi. Mimo wyobrażeń o zawodzie związanym z zainteresowaniami prawdopodobnie dostosuje się do rynku pracy, wytworzonego społecznie myślenia o zawodach konkretnych, przydatnych, ważniejszych. Sugeruje jednak, że relacji między nią, a światem sztuki chciałaby doświadczać nadal.

Na podstawie przeprowadzonej analizy tekstów w tabeli 1 zaprezentowano koncepcje doświadczania niepełnosprawności $\mathrm{w}$ środowisku szkolnym przez osoby z wadą wzroku.

Tabela 1. Koncepcje doświadczania niepełnosprawności

\begin{tabular}{|c|c|c|}
\hline Kondensacja & Kryterium różnicujące & Kategorie opisu \\
\hline $\begin{array}{l}\text { Rozumienie } \\
\text { niepełnosprawności } \\
\text { Codzienność }\end{array}$ & $\begin{array}{l}\text { Ograniczenie, strata, bunt, } \\
\text { dopasowanie, bezradność } \\
\text { Odważne decyzje } \\
\text { Kontekst sytuacyjny, finansowy }\end{array}$ & $\begin{array}{l}\text { 1. Niepełnosprawność jako } \\
\text { dostosowanie i walka w życiu } \\
\text { codziennym }\end{array}$ \\
\hline $\begin{array}{l}\text { Funkcjonowanie w grupie } \\
\text { rówieśniczej } \\
\text { Realizacja obowiązków } \\
\text { szkolnych }\end{array}$ & $\begin{array}{l}\text { Współpraca, pomoc } \\
\text { Świadomość wady } \\
\text { Porównywanie ze „zdrowymi” } \\
\text { uczniami } \\
\text { Inne traktowanie przez } \\
\text { nauczycieli, system szkolny }\end{array}$ & $\begin{array}{l}\text { 2. Niepełnosprawność jako } \\
\text { wsparcie rówieśników } \\
\text { i trudności w uczeniu się }\end{array}$ \\
\hline $\begin{array}{l}\text { Aktywność na zajęciach } \\
\text { rewalidacji } \\
\text { Planowanie przyszłości }\end{array}$ & $\begin{array}{l}\text { Doświadczanie świata } \\
\text { wielozmysłowe } \\
\text { Chęć podejmowania działań } \\
\text { praktycznych } \\
\text { Odkrywanie skrajnych emocji } \\
\text { Różnorodność marzeń }\end{array}$ & $\begin{array}{l}\text { 3. Niepełnosprawność jako } \\
\text { poznawanie świata „inaczej” } \\
\text { i realizowanie marzeń }\end{array}$ \\
\hline
\end{tabular}

Źródło: Opracowanie własne.

\section{Zakończenie}

Niepełnosprawność ujawniona w koncepcjach jest wypadkową znaczeń, które konstruują badani w oparciu o relacje i konteksty społeczne. Postrzeganie to wyznaczają czynniki kulturowe, postawy społeczne innych, przez co niepełnosprawni odczuwają swoje miejsce w społeczeństwie nietypowo, jako przestrzeń, o którą muszą ciągle zabiegać, szybko dostosowywać się do nowych warunków albo ciągle poszukiwać czyjegoś wsparcia. Aspekt zmiany filozoficznej, w realizacji potrzeb edukacyjnych i usuwania barier, jest mało odczuwalny na szkolnych zajęciach przedmiotowych, a specjalna droga nabywania wiedzy i umiejętności ignorowana przez nauczycieli. W grupach społecznych funkcjonują ze świadomością wady, ale niezauważalnie, wykonując obowiązki tak jak inni, chociaż mo- 
gliby z pewnością indywidualizować swoją niepełnosprawność w klasie szkolnej. Najchętniej czynią to na zajęciach rewalidacyjnych, ponieważ tam znajdują pełne zrozumienie. Nadal odczuwalny przez niepełnosprawnych jest aspekt finansowy. Pomimo wszystko wychodzą poza przypisywane im role, ujawniające się bariery. Doświadczając niepełnosprawności nie rezygnują ze swoich marzeń, możliwości osiągnięcia sukcesu społecznego, wolności w pełnieniu ról społecznych, przyszłych zawodowych.

\section{Bibliografia}

Artiles A.J. (1998), The dilemma of difference: Enriching the disproportionality discours with theory and context, "The Journal of Special Education", vol. 32(1), s. 32-36.

Bielecka-Prus J.(2012), Fenomenografia [w:] Stownik socjologii jakościowej, Wydawnictwo Difin, Warszawa.

Curry S.A., P.H., Halten P.H. (2007), Meeting the Unique Educational Needs of Visually Impaired Pupils Through Appropniate Placement, ,JJournal of Visual Impairment \& Blindness, www. eccadvocacy.org/section.aspx?TopiclD=451\&DocumentID-5282 [dostęp: 19.08.2017].

Kirenko J. (2007), Indywidualna i społeczna percepcja niepetnosprawności, Wydawnictwo UMCS, Lublin.

Majewski T. (1983), Psychologia niewidomych i niedowidzących, PWN, Warszawa.

Marek-Ruka M. (2010), Przemiany teorii i praktyki w edukacji osób niepetnosprawnych, „Niepełnosprawność. Półrocznik Naukowy", nr 3, Gdańsk.

Przybylski K. (2010), Znaczenie terminu osoba niepetnosprawna - ku edukacyjnym i społecznym warunkom integracji osób niepetnosprawnych, „Niepełnosprawność. Półrocznik Naukowy”, nr 3, Gdańsk.

Reber A.S. (2002), Stownik psychologii, Wydawnictwo Scholar, Warszawa.

Rozporządzenie MEN z dnia 14.02.2017 r. w sprawie podstawy programowej kształcenia ogólnego dla szkoły podstawowej (Dz. U. z 2017 r., poz. 356).

Smith D.D. (2011), Pedagogika specjalna. Podręcznik akademicki 1, Wydawnictwo APS, PWN, Warszawa.

Standardowe Zasady Wyrównywania Szans Osób Niepełnosprawnych, Rezolucja nr 48/96 Zgromadzenia Ogólnego Narodów Zjednoczonych z dnia 23 grudnia 1993, s. 5, https:// www.rpo.gov.pl/pl/content/akty-prawne-0 [dostęp: 09.08.2017].

Tomaszewski T.(1978), Psychologia, PWN, Warszawa.

Ustawa z dnia 14 grudnia 2016 r. - Prawo oświatowe (Dz. U. z 2017 r., poz. 59).

Netografia:

http://medical-dictionary.thefreedictionary.com/Visual+Impairment. 